Volume 7 Issue 2, June 2020

Nationally Accredited Journal,

Decree No. B/4130/E5/E5.2.1/2019

\title{
The Role And Notary Responsibilities Of Establishment Of A Commanditary Fellow
}

\author{
Nailatul Muna ${ }^{1}$, Cahaya Mutiara Mardiana Putri ${ }^{2}$ and Anis \\ Mashdurohatun $^{3}$
}

\begin{abstract}
The purpose of this study was to: 1) Analyze know their roles and responsibilities in the establishment of the Guild Commanditaire Notary. 2) Obstacles encountered in implementing the Notary's role and responsibility in the establishment of the Guild Commanditaire. 3) The solution or an attempt to overcome the obstacles encountered in implementing the notary's role and responsibility in the establishment of the Guild Commanditaire.

This study using sociological juridical approach or empirical legal research involves studying law from an external perspective to the object of the study of social attitudes and behavior against the law. Sources of primary data from interviews, while secondary data from literature. The study was analyzed by using a descriptive analysis.

The research results are: 1). Roles and responsibilities in the establishment of the Guild Commanditaire Notary is to create legal certainty for the deed he made are authentic and can be used as a means of proving strong and when there are problems associated with the establishment of a limited partnership. Notary also instrumental in the establishment registration Kommanditgesellschaft the Ministry of Law and Human Rights through an online system that is $S A B U$. Notary responsible for storing all documents in the manufacture of the deed of establishment. 2). The obstacles faced by the Notary is the rule about registering through $S A B U$ is still relatively new so in the field occurred constraints for example, many notaries are not yet aware of any changes to the rules and the registration mechanism.

Keywords: Guild Commanditaire; Deed; SABU.
\end{abstract}

\section{Introduction}

This time the people that work to the business world tends to form an association or commonly known as business entities with different objectives. Both aimed for profit, partnership or limited to promote social and religion. The business entity consisting of two (2) forms of business entities that are not business entities are legal entities and business entities are incorporated. Business entities that are not legal entities subdivided into individual business entities which includes the Trade Enterprises (UD) and the business entity is a partnership that includes Maatschaap, Firma, a limited partnership (Vennootschap Commanditaire). ${ }^{4}$

Business development is so fast requires a regulation of business entities that are tailored to the changing times. On August 1, 2018 the government has enacted the Regulation of the Minister of Justice and Human Rights of the Republic of Indonesia Number 17 of 2018 About Registration Commanditaire Guild, Guild Firma, and the Civil

\footnotetext{
1 Student Master of Notary program, Sultan Agung Islamic University Semarang, Email: nailaregina99@gmail.com

${ }^{2}$ Student of Master of Law Program, Faculty of Law, Universitas Islam Sultan Agung email mutiaracahaya98@gmail.com

${ }^{3}$ Lecturer, Faculty of Law, Sultan Agung Islamic University Semarang

${ }^{4}$ Hendricus Subekti, 2012, Badan Usaha, Pengertian, Bentuk dan Tata Cara Pembuatan Aktaaktanya, Yogyakarta: Cakrawala Media, p. v-vi.
} 
Alliance. The regulation is a response to the need for legislation to accommodate the establishment of business entity Commanditaire Guild, Guild Firma, and in accordance with the Civil Alliance era.

There were significant changes in Commanditaire Guild registration under Regulation Minister of Justice and Human Rights of the Republic of Indonesia Number 17 of 2018 About Registration Commanditaire Guild, Guild Firma, and the Civil Alliance. Such changes include online registration. If before registration Guild (CV) / Firm Partnership / Alliance of Civil carried out by the Court, since the entry into force of Permenkumham No. 17 of 2018 concerning the Registration Guild Commanditaire, Firm Partnership and Guild Civil Code, which requires the registration must be made through Administrative System Enterprises ( $S A B U$ ) the Directorate General of Legal Administration (AHU).

Apart from that, anyone who wants to set up a company, Deed is the first step to the process of legality. Enterprises need a deed to authorize any entity that wants to set up. Deed of the Company and authorization, are the basic requirements needed to continue the process of documents required for the company. The company deed done by a notary as public official deed authentic.

Notary birth of needs eraser the people who need someone (figures) are descriptive captions are reliable, trustworthy whose signature and seal guarantees and as strong evidence. An impartial and legal counseling without blemish (onreukbaar / unimpeachable), which shut in making an agreement that would protect in the days to come. This is different from the role of an advocate, which the advocate profession more emphasis on the defense of one's rights when it raised a difficulty, while the Notary profession must act to prevent early difficulties. ${ }^{5}$ Notary is a public official only authorized to make authentic act on all deeds, agreements and determination required by a general rule or a person of interest desired to be stated in an authentic deed, ensure certainty the date, save, give, copy and excerpt, all along the deed was by a general rule not also be assigned or excluded to the officer or others. ${ }^{6}$

Notaries can not perform any action, such as changing the contents of the deed, but he can do that is to care for and pull out a copy of the request of the party whose name is mentioned in the deed or the heirs. Regulation of the Notary office consisting then put in a rule of law that is UUJN. Example of supervision, appointment and dismissal of the notary. With the birth UUJN, there have been a unification of law in setting the Notary in Indonesia and UUJN the written law as a measure for the validity of the Notaries in performing his respective duties. ${ }^{7}$

Based on the foregoing it can be seen that the Regulation of the Minister of Justice and Human Rights of the Republic of Indonesia Number 17 of 2018 About Register Guild Commanditaire, Firm Partnership, and the Guild Civil is the new provisions so that they require an understanding of the notary in carrying out its role and responsibilities in the establishment of the Guild (CV). Under these conditions, in this study will be discussed further on "Roles and Responsibilities of the Notary In Commanditaire Guild Establishment ". This study tried to answer the problem of the role and responsibilities of the Notary in the establishment of the Guild Commanditaire, challenges and

\footnotetext{
${ }^{5}$ Tan Thong Kie, 2000, Book I Notary Studies - Multiple Subjects and All About Practice Notary Buku I Studi Notariat - Beberapa Mata Pelajaran dan Serba-Serbi Praktek Notaris, Jakarta: Ichiar Baru Van Hoeve, p. 102

${ }^{6}$ Habib Adjie, 2008, Hukum Notaris Indonesia, Tafsir Tematik Terhadap UU No, 30 Tahun 2004 tentang Jabatan Notaris, Bandung: Refika Aditama, p. 13

${ }^{7}$ Soegianto, 2015, Etika Profesi dan Perlindungan Hukum Bagi Notaris, Yogyakarta: Farisma Indonesia, p. 13
} 
Volume 7 Issue 2, June 2020

Nationally Accredited Journal,

Decree No. B/4130/E5/E5.2.1/2019

solutions faced in implementing the Notary's role and responsibility in the establishment of the Guild Commanditaire.

\section{Research methods}

This study using sociological juridical approach or empirical legal research involves studying law from an external perspective to the object of the study of social attitudes and behavior against the law. ${ }^{8}$ This type of research conducted by the author belonging to the descriptive analytical research. Primary data is data derived from the study site obtained through observation and in-depth interviews, ${ }^{9}$ while secondary data obtained through the literature, the results of the analysis will be presented descriptively.

\section{Results and Discussion}

\subsection{Roles and responsibilities of the Notary in the establishment of the Guild Commanditaire}

Notary deed was instrumental in creating legal certainty for its authentic nature and can be used as a means of proving strong and when there are problems associated with the deed. Today the need for an authentic deed as proof increasing with the business relationship in various fields of business both from local and international scale. ${ }^{10}$

Guild Commanditaire (Commanditaire Vennotschaap), hereinafter referred CV is a partnership established by one or more allies limited partnership with one or more complementary ally, to run the business continuously. ${ }^{11}$

The role of the Notary in terms of a deed associated with CV, in general, a deed of Notary associated with CV can be distinguished among others: CV Deed of Establishment and Amendment of Articles of Association can also Deed CV and CV branch opening. Typically establishment does not require certain formalities CV, CV Incorporation can be done either orally or in writing, either by deed under hand or authentic deed. There is no obligation to register and published in the State Gazette of the Republic of Indonesia for the establishment of the Guild Commanditaire CV. If the parties want the certificate of incorporation Guild Commanditaire CV made before a notary is by itself by using authentic deed.

Establishment CV can be done in writing or orally, whether an authentic deed or under the hand, there is no requirement for registration and announcement in the State Gazette of the Republic of Indonesia in the establishment CV. But in the Deed of Establishment of legal certainty CV should be made by / before a notary as provided for in Article 22 KUHD must be founded on an authentic deed, but the absence of such certificate, can not be put forward to the detriment of the public / third party. In practice in Indonesia has shown a habit that people set up CV based on Deed

\footnotetext{
${ }^{8}$ I Made Pasek Diantha, 2017, Metodologi Penelitian Hukum Normatif dalam Justifikasi Teori Hukum, Jakarta: Prenada Media Group, p. 12

${ }^{9}$ Faisal Ananda P. Arfa, 2016, Metodologi Penelitian Hukum Islam, Jakarta: Kencana, p. 180.

${ }^{10}$ Sjaifurahman \& Habi Adjie, 2011, Aspek Pertanggungjawaban Notaris dalam Pembuatan Akta, Bandung: CV. Mandar Maju, p. 8.

${ }^{11}$ Article 1 (1) of the Regulation of the Minister of Law and Human Rights No. 17 of 2018 About Registration Commanditaire Guild, the Guild and Guild Civil Firma
} 
(Authentic), registered in the District Court competent authorities and published in the Official Gazette of Republic of Indonesia. ${ }^{12}$

According Permenkumham 172018 About Registration Commanditaire Guild, Guild Firma, and the Civil Alliance of Article 3 paragraph (1) and (2) it is stated that the establishment registration application CV, Firm, and Civil Guild filed by the applicant to the Minister. The appeal was filed by the Business Entity Administration System. On the Permenkumham establishment registration application must be preceded by the submission of CV name. Petitioner filed a petition submission to the Minister through the name CV Business Entity Administration System. Name CV submitted must meet the following requirements:

- Written with Latin letters.

- Not to be used legally by CV in the Business Entity Administration System;

- Not contrary to public order and / or morality;

- Not the same or similar to the name of the state institutions, government agencies, international agencies except by permission of the agency; and

- Does not consist of a number or series of numbers, letters, or a series of letters that do not form words.

The submission of names is done by filling Submission Format Name. Submission Format Name at least contain: user consent payment number CV name of the bank's perception; and the name of CV booked. Approval of use of the name given by the Minister CV electronically. Approval least contain: CV name booking number, name CV wearable, reservation date, expiration date, and the payment code.

CV establishment registration application must be filed by the applicant through the Business Entity Administration System. Application should be submitted no later than 60 (sixty) days from the date of the deed of establishment CV has signed. Request made by filling out a registration Format. If the CV exceeds establishment registration period CV establishment registration application can not be submitted to the Minister. Based on the Permenkumham No. 17 of $2018:^{13}$

Applicant is the founder together or allies who will register a CV, Firm, and Guild Code that provides power to the Notary to apply via the Business Entity Administration System.

After the Minister issues SKT CV / Guild Commanditaire at the time the application is accepted, it is delivered to the applicant SKT electronically. So the next task is to print SKT notary such, it is in accordance with Permenkumham No. 17 of 2018:

Notary can immediately make its own molding SKT CV, Firm, and the Civil Alliance, using a white paper the size of F4 / folio with a weight of 80 (eighty) gram. SKT referred to in paragraph (3) shall be signed and stamped by the Notary office and contains the phrase stating "Registration Certificate is printed on the Business Entity Administration System". ${ }^{14}$

Besides a role in deed and applying through the Business Entity Administration System $(\mathrm{SABH})$, a notary is also responsible for preserving documents that made the deed of establishment, it is described in Permenkumham No. 17 of 2018:

Documents for registration CV, Firm, and the Civil Alliance as referred to in paragraph (2) stored Notary, which includes:

- The certificate of incorporation CV, Firm, and the Civil Alliance least contain;

\footnotetext{
${ }^{12}$ Ayu Ratnawati, Role For Making Notary Deed of Establishment (CV) In the Create Rule of Law, Repertorium Journal, Volume Ii No. July 2nd December 2015, p. 160

${ }^{13}$ Article 1, paragraph 6 Permenkumham No. 17 of 2018

${ }^{14}$ Article 14 paragraph (3) and (4) Permenkumham No. 17 of 2018
} 
Volume 7 Issue 2, June 2020

Nationally Accredited Journal,

Decree No. B/4130/E5/E5.2.1/2019

- founder identity consisting of founder's name, residence, and occupation;

- business activities;

- rights and obligations of the founders; and

- period CV, Firm, and the Civil Alliance.

- Copy of the complete address information about CV, Firm, and the Civil Alliance. ${ }^{15}$

In addition through the electronic system of registration Guild Commanditaire can also be through non-electronic, it is stipulated in Permenkumham No. 1 2018:

- In the case of an application for registration of the establishment, registration of changes in the constitution, and the dissolution of the CV, Firm and the Civil Alliance can not be filed electronically, as caused by the following things:

- Notary that domicile is not available over the internet.

- Business Entity Administration System is not functioning properly based on the official announcement by the Minister, the applicant may apply in non-electronic.

- Application referred to in paragraph (1) shall be submitted in writing by attaching:

- Supporting documents.

- Letter from the Head of the local Telecommunications Office which stated that the seat of the Notary who has not yet reached by the internet facility. ${ }^{16}$

Where previously the registration CV / Firm / Guild of Civil carried out by the Court, dated August 1, 2018 have come into force Permenkumham No. 17 of 2018 concerning the Registration Guild Commanditaire, Firm Partnership and Guild Civil Code, which requires the registration must be made through Administrative System Enterprises $(S A B U$ ) on Directorate General Legal Administration (AHU). Implementation of registration CV / Firm / online Civil Alliance adopts the online registration system PT that has lasted until today.

The responsibilities of a notary for involvement in the manufacture of a limited partnership deed of incorporation of incorporation deed restricted to editorial made. If there are errors or omissions which led to the deed which was made into a deed which only has the strength of evidence as a deed under hand or null and void, then the notary shall be responsible for losses suffered by the client to pay the indemnity. Notary is responsible for ensuring that the deed of incorporation of a limited partnership that made it has the strength of evidence was perfect with the certainty and the protection of the law clearly define the rights and obligations of the parties hereto. ${ }^{17}$

\subsection{Obstacles and solutions encountered in implementing the Notary's role and responsibility in the establishment of the Guild Commanditaire}

Notary Public is the official authorized to make an authentic deed and others referred to the authority and the Constitution of the country. Notary instrumental task in the field of civil law, and to the notary qualified as a General Officer who is authorized to make an authentic deed, and the deed is the formulation of desire or the will of the

\footnotetext{
${ }^{15}$ Article 12 paragraph (4) Permenkumham No. 17 of 2018

${ }^{16}$ Article 21 Permenkumham No. 17 of 2018

17 Indarajati Arlita, 2010, Peranan notaris dalam pembuatan akta pendirian persekutuan komanditer di Kabupaten Klaten, Jogjakarta: Journal of Gadjah Mada University
} 
parties set forth in the notarial deed made before or by the Notary, and other authorities. ${ }^{18}$

Deed has two important functions, namely a formal function and the function of evidence. Formal function means that a legal act should be made a deed. Functions evidence deed was made originally intentionally to establish a verified later. The nature of an agreement written in the form of a deed that does not make the validity of the agreement but to be used as evidence at a later date. ${ }^{19}$

Rules on the registration CV / Firm / Civil Alliance through $S A B U$ is still relatively new so in the field occurred constraints for example, many notaries are not yet aware of any changes to the rules and the registration mechanism. The new rules also impact on the CV / Firm / Guild Code that already existed prior to the passage Permenkumham No. 17 of 2018. All CV / Firm / Guild Civil Code still have to register legality of Agency efforts through $S A B U$ (recording registration). The grace period given is for one year, just that there was no sanction for FIRMA / CV / Guild Code that do not register or too late to register. All returned to the relevant business entities, because the registration is related to the credibility of the CV / Firm / Civil Guild itself. ${ }^{20}$ CV registration and establishment of arrangements there are two (2) the rule of law in its regulation. First, according to Article 23 KUHD mention that The Limited Firma certificates are obliged to register it in the register provided for it in the secretariat of the Raad van Justitie (District Court) of Regional Law of the Company's domicile. Secondly, according to Permenkumham No. 172018 About Registration Commanditaire Guild, Guild Firma, and the Civil Alliance of Article 3 paragraph (1) and (2) it is stated that the establishment registration application CV, Firm, and Civil Guild filed by the applicant to the Minister. The appeal was filed by the Business Entity Administration System. Establishment of two basic legal norms CV conflicts between them, juridical norm contradictions and practical legal solutions need to be reviewed. Conflicts of norms led to an absence of legal certainty in the establishment CV.

Associated with the position of the Commercial code as the Law and the Regulation of the Minister of Law and Human Rights No. 17 of 2018 as a form of regulation that specifically regulates the establishment and registration of CV pursuant to Article 7 (2) states legal force legislation in accordance with the hierarchy as referred to in paragraph (1). While the explanation of Article 7, paragraph 2) states that "in this provision is meant by" hierarchy "is in every legislation based on the principle of lower legislation may not contradict higher laws and regulations".

Socialization related to the Notary government's new regulations also play an important role for the smooth implementation of the responsibilities of a notary role in making authentic deeds, especially on a limited establishment registration. The way out because there are two legal options that are used both in terms of the law more specific and law of higher social status, it should be in the registration of establishments CV done on both the agency designated in the legislation, which is in accordance with the provisions of article 23 KUHD Office District Court Clerk where CV is a resident and according to the provisions of article 3 Permenkumham No. 17 of 2018 registered with the Ministry of Law and Human Rights through the Business Entity Administration System ( $S A B U$ ) online.

\section{Closing}

\footnotetext{
18 AryaniWitasari, MPD Bukan Advokat Para Notaris Berdasarkan Undang-Undang No.30 Tahun 2004 Tentang Jabatan Notaris, Law Journal, Vol XXVIII, No. 2, December 2012, p.885

19 Sudikno Martokusumo, 1999, Mengenal Hukum Suatu Pengantar, Yogyakarta: Liberty, p.121

${ }^{20}$ Interview with Mr. Subiyanti, Notary PPAT in the city, 9 November 2019
} 
Volume 7 Issue 2, June 2020

Nationally Accredited Journal,

Decree No. B/4130/E5/E5.2.1/2019

\subsection{Conclusion}

Based on the description above, the conclusions of this research are:

- Roles and responsibilities in the establishment of the Guild Commanditaire Notary is to create legal certainty for the deed he made are authentic and can be used as a means of proving strong and when there are problems associated with the establishment of a limited partnership. Notary also instrumental in the establishment of CV registration at the Ministry of Justice and Human Rights through an online system that is $S A B U$. Notary responsible for storing all documents in the manufacture of the deed of establishment. Notaries are also responsible in doing their own printing SKT approved, use white paper size F4 / folio with a weight of 80 (eighty) gram.

- Constraints faced by the Notary in carrying out their roles and responsibilities in the establishment of the Guild Commanditaire are the rules concerning the registration of CV / Firm / Guild Civil through $S A B U$ is still relatively new so in the field occurred constraints for example, many notaries are not yet aware of any changes to the rules and mechanisms of such registration. Solutions that can be done is with the socialization of the government related to the Notary the new regulations, because it plays an important role for the smooth implementation of the responsibilities of a notary role in making authentic deeds, especially on a limited establishment registration.

\subsection{Suggestion}

- To the notary to ensure legal certainty in the registration of establishments CV to keep referring to the applicable laws and regulations, including in its application.

- To the general public who will take care of the registration of establishment CV to adhere to laws and regulations applicable in a variety of existing laws.

- To the legislators to immediately create a single rule of the registration of establishments CV which emphasizes the principle of legal certainty and legal regulations such as government regulation as the implementing regulations, including instructions on the technical implementation of the registration of establishment CV, socialization to the Notary must often be done in order to avoid overlapping in the implementation of the establishment CV between KUHD and Permenkumham Nomor17 2018.

\section{References}

[1] Aryani Witasari, MPD Bukan Advokat Para Notaris Berdasarkan Undang-Undang No.30 Tahun 2004 Tentang Jabatan Notaris, Law Journal, Vol XXVIII, No. 2 December 2012

[2] Ayu Ratnawati, Peranan Notaris Untuk Pembuatan Akta Pendirian (CV) Dalam Mewujudkan Kepastian Hukum, Repertorium Journal, Volume Ii No. July 2nd December 2015

[3] Habib Adjie, 2008, Hukum Notaris Indonesia, Tafsir Tematik Terhadap UU No, 30 Tahun 2004 tentang Jabatan Notaris, Bandung: Refika Aditama

[4] Hendricus Subekti, 2012, Badan Usaha, Pengertian, Bentuk dan Tata Cara Pembuatan Akta-aktanya, Yogyakarta: Horizon Media 
eISSN : 2581-2114, pISSN: 2406-9426

[5] I Made Pasek Diantha, 2017, Metodologi Penelitian Hukum Normatif dalam Justifikasi Teori Hukum, Jakarta: Prenada Media Group

[6] Indarajati Arlita, 2010, Peranan notaris dalam pembuatan akta pendirian persekutuan komanditer di Kabupaten Klaten, Yogyakarta: Journal of Gadjah Mada University

[7] Faisal Ananda P. Arfa, 2016, Metodologi Penelitian Hukum Islam, Jakarta: Kencana

[8] Regulation of the Minister of Law and Human Rights No. 17 of 2018 About Registration Commanditaire Guild, the Guild and Guild Civil Firma

[9] Sjaifurahman \& Habi Adjie, 2011, Aspek Pertanggungjawaban Notaris dalam Pembuatan Akta, Bandung: CV. Mandar Maju

[10] Soegianto, 2015, Etika Profesi dan Perlindungan Hukum Bagi Notaris, Yogyakarta: Farisma Indonesia

[11] Sudikno Martokusumo, 1999, Mengenal Hukum Suatu Pengantar, Yogyakarta: Liberty

[12] Tan Thong Kie, 2000, Buku I Studi Notariat - Beberapa Mata Pelajaran dan Serba-Serbi Praktek Notaris, Jakarta: Ichiar Baru Van Hoeve

[13] Law No. 2 of 2014 concerning Notary 